\title{
EFFECTS OF WATER TURBULENCE ON PLANT, SEDIMENT AND WATER QUALITY IN REED (Phragmites australis) COMMUNITY
}

\author{
KEERTHI SRI SENARATHNA ATAPATHTHU ${ }^{1,4 *}$, TAKASHI ASAEDA ${ }^{1,5}$, MASUMI \\ YAMAMURO $^{2}$, HIROSHI KAMIYA ${ }^{3,6}$ \\ ${ }^{1}$ Department of Environmental Science and Technology, Saitama University, 255 Shimo-okubo, Sakura-ku, Saitama 338-8770, Japan \\ ${ }^{2}$ Department of Natural Environmental Studies, Graduate School of Frontier Sciences, The University of Tokyo,5-1-5 \\ Kashiwanoha, Kashiwa 277-8563, Japan \\ ${ }^{3}$ Shimane Prefectural Institute of Public Health and Environmental Science, 582-1 Nishihamasadacho, Matsue 690-0122, Japan \\ ${ }^{4}$ Department of Limnology and Water Technology, Faculty of Fisheries and Marine Sciences and Technology, Uni- \\ versity of Ruhuna, Matara, Sri Lanka; e-mail: atapaththu@gmail.com, keerthi@fish.ruh.ac.lk \\ ${ }^{5}$ Research Institute of Chuo University, Kasuga, Bunkyo, Tokyo 112-8551, Japan \\ ${ }^{6}$ Research Center for Coastal Lagoon Environments, Shimane University, 1060 Nishikawatsu, Matsue, Shimane 690-8504, Japan
}

${ }^{*}$ Author for correspondence

Abstract

Atapaththu K.S.S., Asaeda T., Yamamuro M., Kamiya H.: Effects of water turbulence on plant, sediment and water quality in reed (Phragmites australis) community. Ekológia (Bratislava), Vol. 36, No. 1, p. 1-9, 2017.

Even though the interaction between water movements and aquatic plant is crucial for the aquatic ecosystem management, the importance of water turbulence in this regard is not well documented. To add to our knowledge on the interaction between aquatic plant communities and water turbulence, this study examined turbulence, plant, sediment and water quality at the reed community (Phragmites australis) in the Lake Shinji, Japan. Observations were conducted along transects perpendicular to the shoreline. For each transect, reed communities were observed at land ward side, centre, water ward and the outside of the reed community. An elevated level of turbulence was observed outside compared to inside reed community, where the magnitude of turbulence decreased with distance into the community interior. A significant positive correlation was observed for turbulence and surface-dissolved oxygen where the latter was negatively correlated to reed density. Sediment composition was affected by water turbulence where the content of coarse particles positively correlated to turbulence. Accumulation of organic matter in anoxic sediments together with fine particles was observed under low turbulence. Our findings can offer insight into understanding the interactions between turbulence and aquatic plant communities.

Key words: turbulence, Phragmites australis, Lake Shinji, sediments, dissolved oxygen.

\section{Introduction}

Aquatic plants play a vital role to keep the integrity of aquatic ecosystems where those plants are involved either directly or indirectly in a vast array of ecological functions. Primary pro- 
duction, provisioning of habitat and food for aquatic fauna, contributing to the biogeochemical cycling are some of the well-known ecological functions of aquatic plants. These plants are persistently challenged by numerous environmental fluctuations as a consequence of dynamic nature of the aquatic systems (Bal et al., 2011). The resistance or resilience against disturbance depends on local environmental conditions (Bernhardt-Römermann et al., 2011).

Water movements decided many ecological functions and processes not only in aquatic plants but also in the entire aquatic ecosystems due to flow-driven drags and lift forces (Madsen et al., 2001). Temporal variability at any point in a water body leads to rapid fluctuations of the flow velocity with the passage of turbulent eddies (Sand-Jensen, Pedersen, 1999) where the most lake, river and estuarine flow motions are often turbulent (Horne, Goldman, 1994). Flow turbulence and wave forces are extremely complex, and their magnitude and direction can change rapidly in many natural environments (Schutten et al., 2004). Therefore, water movements make either positive or negative impact in a magnitude-dependent manner. For instance, water level fluctuations strongly affect to the growth of macrophytes in middle and lower eulittoral zone (Krolova et al., 2013). Different responses for these circumstances, including variations in biomass allocation, plant growth and morphological variations, have been exhibited in plants (Asaeda et al., 2010a,b; Bornette, Puijalon, 2011; Silinski et al., 2015). Flow regimes and hydraulics are commonly cited as the main abiotic determinants that affect the architecture of the aquatic systems by altering the distribution and assemblages of plant communities (Chambers et al., 1991; Green, 2005; Olson et al., 2012; Thomaz et al., 2007). Further, water turbulence has been identified as one of the main abiotic stress factors of macrophytes (Atapaththu, Asaeda, 2014; Ellawala et al., 2012).

The common reed (Phragmites australis) is a widespread and dominant emergent plant species that plays a significant ecological role in many wetland ecosystems (Engloner, 2009; Horppila et al., 2013; Struyf et al., 2007). Reeds along the coastal belts are often exposed to water turbulence. Even though the effects of reed communities on turbulence have been studied up to some extent (Coops, Van der Velde, 1996; Horppila et al., 2013; Leonard, Croft, 2006), turbulence-driven variation in reed communities and the effects of turbulence on ecological functions of the reed communities are less documented. Understanding the mechanisms behind the interaction between water movements and plant communities are particularly important for planning criteria that would be of benefit in aquatic ecosystem managements. Lake Shinji, situated on the eastern side of Shimane Prefecture, Japan, is a shallow brackish-water system having an ecologically important reed belt along their coast (Asaeda, Shinohara, 2012; Horinouchi et al., 2008). To add to our knowledge on flow plant interactions in aquatic ecosystems, the present study examined the ecological significance of water turbulence in relation to plant, sediment and the dissolved oxygen in the reed community (P. australis) of the Shinji Lake.

\section{Methodology}

Study site

This study was carried out in a mono-species P. australis communities situated along the coastal belt (Fig. 1) of Lake Shinji, Japan from August to September 2013. This lake is an oligohaline lagoon with a salinity range of 1-10 psu. The 
lake covers a surface area of $79.1 \mathrm{~km}^{2}$ and its basin is $288.4 \mathrm{~km}^{2}$. The maximum depth of the lake is $6.4 \mathrm{~m}$, while the average depth is $4.5 \mathrm{~m}$ (Komuro et al., 2016). Five sampling points (L1-L5) were selected along the west coast of the lake (Fig. 1). The L1 site was near the mouth of the Hii River whereas the other locations are situated along the coastal belt (Fig. 1). For each location, three quadrates $\left(50 \times 50 \mathrm{~cm}^{2}\right)$ along the transect perpendicular to the shoreline were studied; i.e. near the landward (Landward), middle of the reed community (Middle) and near the waterward edge of the reed community (waterward). Water turbulence at the surface water $(\sim 2-3 \mathrm{~cm}$ below the surface) was measured using a two-dimensional electromagnetic current meter (EMCM) (SF-5712, Tokyo-Keisoku Company Ltd., Tokyo, Japan). For each point, velocity fluctuations were recorded for at least three minutes, and the average turbulence velocity (mean square root) was calculated (Green, 2005). To observe the turbulence reduction of reed communities, turbulence measurements were also taken at the outside of the reed communities $(\sim 2-3 \mathrm{~m}$ away from the outer edge of the reed community). Because of practical difficulties in access, only two locations (near the outer edge of L 3 and L5) were observed to measure the water turbulence outside reed community.

Water depth of each sampling point was recorded using a depth gauge. Dissolved oxygen content of surface water (DO) was measured using a water quality monitor (Horiba, Kyoto, Japan). At the same time, the oxygen redox potential $\left(E_{h}\right)$ of the substrate sediments $(\sim 5 \mathrm{~cm}$ below the surface) was measured using a pH meter (Thermo Scientific, ORION 3 STAR). Light intensity inside the reed communities was monitored at every $10 \mathrm{~cm}$ from the top of the canopy of reeds using a light meter (HIOKI-060923411). The light intensity at the outside of the reed community was also measured to calculate the light intensity ratio between inside to outside.

After measuring the physicochemical properties, plants and sediments were sampled from each location. All reeds found within a quadrate of $50 \times 50 \mathrm{~cm}^{2}$ were totally removed with both above-ground (leaves and stem) and belowground portions (roots and rhizomes). The number of stems was counted to determine the stem density. The height of each stem was individually measured using a measuring tape. Two sediment core samples were collected from each location for subsequent analysis. Plants and sediments were transported to the laboratory in a cooling condition.

Plant samples were separated to above ground (ABG) and below ground (BGB) parts. The diameter of the rhizomes was individually measured using a digital vernier caliper. For each rhizome, the average diameter was calculated after measuring the diameter of each internode $(n=5-12)$. ABG and BGB portions were separately ovendried at $70^{\circ} \mathrm{C}$ until a constant weight is obtained to determine the dry weight. Sediment samples were also oven-dried and the dried samples were sieved through a standard sieve set for particle size distribution. Sediment organic matter content was determined after burning overnight at $550^{\circ} \mathrm{C}$ in a muffle furnace.

\section{Statistical analysis}

The results are presented as mean $\pm \mathrm{SD}$. Data were subjected to one-way analysis of variance (one-way ANOVA) followed by Dunkan's multiple range test to evaluate the mean difference at the 0.05 significant level. Pearson correlation was employed to determine the relationship between the tested parameters. Graphical illustrations were made using MSExcel while the statistical analyses were performed using Statistical Package for the Social Sciences (SPSS) v16.0.

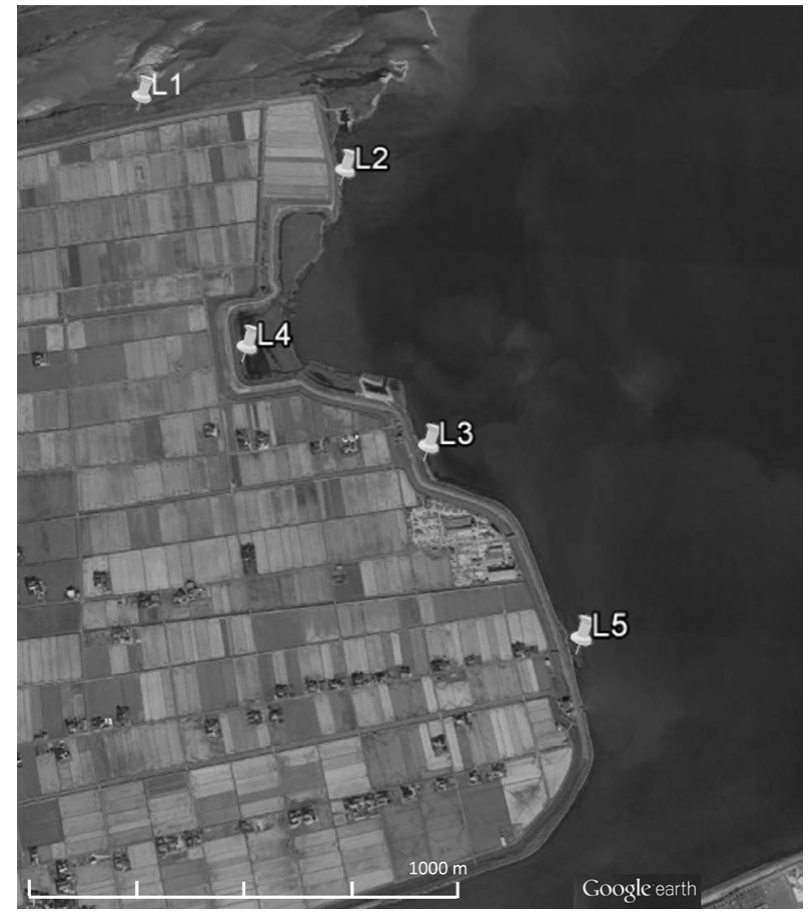

Fig. 1. Location of five study sites (L1-L2). 


\section{Results and discussion}

Water turbulence ranged from 0.14 to $0.50 \mathrm{~cm} \mathrm{~S}^{-1}$ and, the magnitude of turbulence outside the reed communities was significantly higher than that of the inside (Table 1). Compared to outside, reeds reduce water turbulence by $50-60 \%$ towards interior to the reed community. A combination of plant baffling and frictional effects could reduce water turbulence along the reed community (Reed 2003). Similar to the present study, approximately $50 \%$ of the initial velocity reduction within the distance of $5 \mathrm{~m}$ from the canopy edge has been reported (Leonard, Croft, 2006; Leonard, Reed, 2003).

Dissolved oxygen concentration (DO) was significantly different among study sites ( $F$ $=4.81, p<0.05)$, where the DO content outside reed communities was significantly higher than those inside the reed community. Further, there was a positive correlation between DO

T a b l e 1. Turbulence, dissolved oxygen content of surface water (DO), sediment redox potential (Eh), Sediment Organic matter Content (OMC), plant biomass (Above ground biomass (ABG) and below ground biomass (BGB)), stem density, stem height and rhizome diameter of $P$. australis.

\begin{tabular}{|c|c|c|c|c|c|c|}
\hline Parameter & & Land ward & Middle & Water ward & Out side & p-value \\
\hline \multirow[t]{3}{*}{ Turbulence $\left(\mathrm{cms}^{-1}\right)$} & Min & 0.14 & 0.22 & 0.25 & 0.63 & \\
\hline & Max & 0.49 & 0.36 & 0.44 & 0.73 & \\
\hline & Avg & $0.25 \pm 0.13$ & $0.30 \pm 0.06$ & $0.30 \pm 0.08$ & $0.68 \pm 0.07$ & $p<0.05$ \\
\hline \multirow[t]{3}{*}{$\mathrm{DO}(\mathrm{ppm})$} & Min & 0.95 & 0.72 & 0.87 & 7.42 & \\
\hline & Max & 3.86 & 6.02 & 6.01 & 7.50 & \\
\hline & Avg & $1.8 \pm 1.1$ & $2.1 \pm 2.1$ & $2.3 \pm 2.4$ & $7.4 \pm 0.05$ & $p<0.05$ \\
\hline \multirow[t]{3}{*}{ Sediment Eh (mv) } & Min & -170.0 & -106.0 & -92.7 & -80.0 & \\
\hline & Max & -62.8 & -30.0 & -50.0 & -65.0 & \\
\hline & Avg & $-93.5 \pm 77.2$ & $-74.4 \pm 31.9$ & $-74.5 \pm 22.0$ & $-72.5 \pm 10.0$ & $p>0.05$ \\
\hline \multirow{3}{*}{$\begin{array}{l}\text { Sediment OMC } \\
(\%)\end{array}$} & Min & 0.58 & 0.29 & 0.26 & 0.48 & \\
\hline & Max & 1.79 & 1.59 & 2.14 & 0.50 & \\
\hline & Avg & $1.03 \pm 0.52$ & $0.82 \pm 0.53$ & $1.02 \pm 0.98$ & $0.49 \pm 0.01$ & $p>0.05$ \\
\hline \multirow{3}{*}{$\begin{array}{l}\text { ABG } \\
\left(\mathrm{kg} \mathrm{DW} \mathrm{m}^{-2}\right)\end{array}$} & Min & 0.19 & 0.19 & 0.19 & - & \\
\hline & Max & 2.63 & 1.38 & 1.35 & - & \\
\hline & Avg & $1.40 \pm 0.96$ & $1.08 \pm 0.50$ & $0.86 \pm 0.46$ & - & $p>0.05$ \\
\hline \multirow{3}{*}{$\begin{array}{l}\text { BGB } \\
\left(\mathrm{kg} \mathrm{DW} \mathrm{m}^{-2}\right)\end{array}$} & Min & 0.04 & 0.04 & 0.04 & - & \\
\hline & Max & 0.43 & 0.56 & 0.50 & - & \\
\hline & Avg & $0.24 \pm 0.16$ & $0.28 \pm 0.19$ & $0.24 \pm 0.19$ & - & $p>0.05$ \\
\hline \multirow{3}{*}{$\begin{array}{l}\text { Stem density } \\
\left(\text { stems } \mathrm{m}^{-2}\right)\end{array}$} & Min & 84 & 64 & 76 & - & \\
\hline & Max & 304 & 240 & 256 & - & \\
\hline & Avg & $192 \pm 83$ & $163 \pm 68$ & $175 \pm 76$ & - & $p>0.05$ \\
\hline \multirow[t]{3}{*}{ Stem height $(\mathrm{cm})$} & Min & 118 & 124 & 138 & - & \\
\hline & $\operatorname{Max}$ & 214 & 193 & 191 & - & \\
\hline & Avg & $155 \pm 40$ & $161 \pm 26$ & $161 \pm 26$ & - & $p>0.05$ \\
\hline \multirow{3}{*}{$\begin{array}{l}\text { Rhizome diameter } \\
(\mathrm{cm})\end{array}$} & Min & 0.76 & 0.57 & 0.75 & - & \\
\hline & Max & 1.01 & 0.91 & 1.11 & - & \\
\hline & Avg & $0.89 \pm 0.12$ & $0.75 \pm 0.14$ & $0.88 \pm 0.15$ & - & $p>0.05$ \\
\hline
\end{tabular}


$\mathrm{T}$ a b l e 2. Correlation matrix for turbulence, biomass, stem density, OMC, ORP and sediment particles.

\begin{tabular}{|c|c|c|c|c|c|c|c|c|c|c|c|c|}
\hline & \multirow{2}{*}{ Turbulence } & \multirow{2}{*}{$\begin{array}{c}\text { Biomass } \\
\text { ratio }\end{array}$} & \multirow{2}{*}{$\begin{array}{c}\text { Surface } \\
\text { water } \\
\text { DO }\end{array}$} & \multirow{2}{*}{$\begin{array}{c}\text { Stem } \\
\text { density }\end{array}$} & \multirow{2}{*}{ OMC } & \multicolumn{6}{|c|}{$\%$ of sediment particle size } \\
\hline & & & & & & & 1000 & 500 & 250 & 125 & 63 & $<63$ \\
\hline \multicolumn{2}{|c|}{ Biomass ratio } & -0.16 & & & & & & & & & & \\
\hline \multicolumn{2}{|c|}{$\begin{array}{l}\text { Surface water } \\
\text { DO }\end{array}$} & $0.55^{*}$ & 0.12 & & & & & & & & & \\
\hline \multicolumn{2}{|c|}{ Stem density } & 0.41 & 0.09 & $-0.77^{*}$ & & & & & & & & \\
\hline \multicolumn{2}{|l|}{ OMC } & -0.13 & -0.09 & -0.17 & -0.15 & & & & & & & \\
\hline \multirow{6}{*}{ 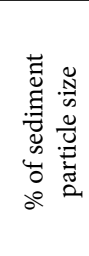 } & 1000 & 0.32 & -0.18 & $-0.60^{*}$ & 0.45 & -0.39 & & & & & & \\
\hline & 500 & -0.24 & -0.32 & -0.15 & 0.27 & $-0.61^{*}$ & -0.20 & & & & & \\
\hline & 250 & -0.18 & 0.46 & 0.54 & -0.30 & 0.46 & $-0.84^{*}$ & 0.07 & & & & \\
\hline & 125 & -0.21 & 0.34 & $0.73^{*}$ & $-0.65^{*}$ & $0.48^{*}$ & $-0.85^{*}$ & -0.34 & $0.74^{*}$ & & & \\
\hline & 63 & -0.20 & 0.20 & $0.56^{*}$ & $-0.58^{*}$ & $0.54^{*}$ & $-0.91^{*}$ & $-0.62^{*}$ & $0.61^{*}$ & $0.95^{*}$ & & \\
\hline & $<63$ & -0.17 & 0.12 & 0.41 & -0.49 & $0.59^{*}$ & $-0.86^{*}$ & $-0.59^{*}$ & $0.50^{*}$ & $0.87^{*}$ & $0.98^{*}$ & \\
\hline \multicolumn{2}{|l|}{ ORP } & 0.31 & -0.61 & 0.01 & 0.27 & $-0.64^{*}$ & 0.49 & 0.38 & -0.57 & $-0.61^{*}$ & $-0.61^{*}$ & -0.56 \\
\hline
\end{tabular}

( ${ }^{*}$ indicates the significance at 0.05 level)

content and water turbulence (Table 2). Dense reeds reduce gas diffusion at the air-water interface and it was explained by the observed negative correlation between stem density and DO content (Table 2). Turbulence is one of the physical mechanisms that enhance mixing atmospheric air with surface waters at the air-water interface. As turbulence reduction was observed interior to the reed community, this may further reduce the capability of dissolving atmospheric air with surface waters. On the other hand, high stem density further reduces the available surface area for mixing at the air-water interface. Therefore, high stem densities together with a reduction in turbulence reduce dissolved oxygen inside reed communities. Even though the atmospheric oxygen dissolves in the surface water at the air-water interface, the rate of gas diffusion is slower in water than air (Madsen et al., 2001). Furthermore, there was a negative correlation between above ground biomass (AGB) and DO content $(R=$ $-0.71, p<0.05)$. The presence of dense reeds reduces light penetration towards surface water, leading to receiving less than $10 \%$ light intensity compared to outside (Fig. 2). Therefore, low-light availability might impair the primary production in surface water as effectively shading out algae

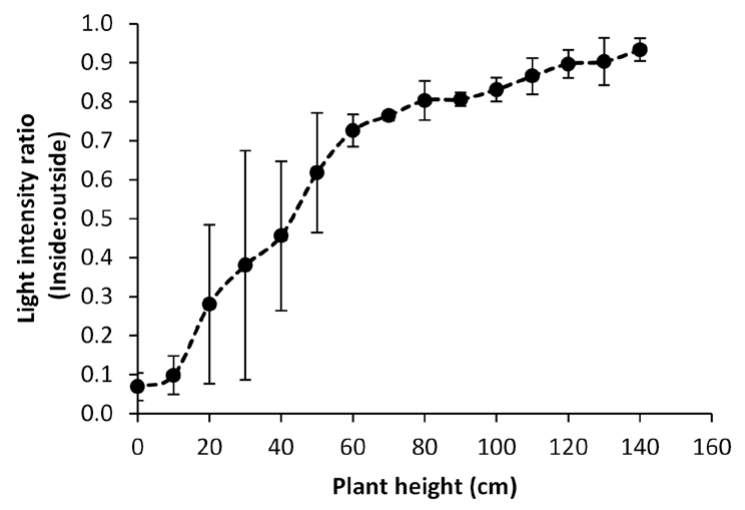

Fig. 2. Relationship between light intensity and height of reeds. 
in the water beneath the Phragmites canopies (Hans, 1994). That could be another possible explanation for the low dissolved oxygen in water column responding to increased stem density.

High turbulent water reduces the chance of organic matter accumulation in bottom sediments. This was clearly explained by the observed negative correlation between turbulence and OMC (Table 2 and Fig. 3). At the outside where sediments are highly exposed to turbulence, they have comparatively less OMC (Table 2) while approximately a maximum of fourfold higher accumulation was found inside the community (Table 1 and Fig. 3).

Aquatic sediments are vulnerable to water movements as the latter often disturb the bottom sediments. This disturbance induces re-suspension of sediments in aquatic systems (Madsen et al., 2001) and consequently reduce organic matter accumulation in bottom sediments. Despite anoxic sediments were found in both inside and outside reed communities;

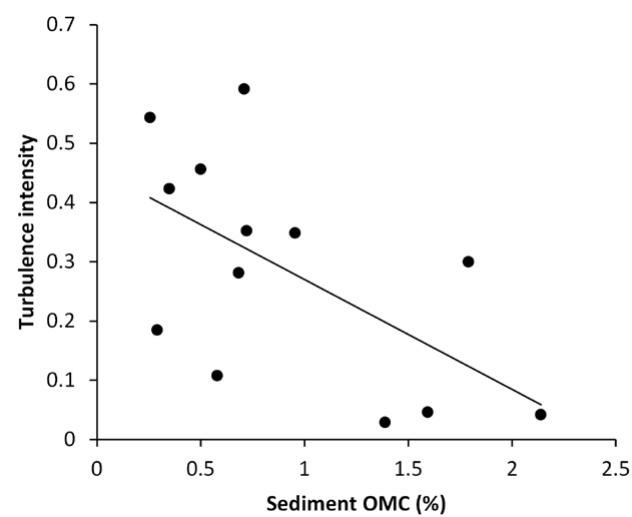

Fig. 3. observed trend in sediment Organic matter content (OMC) and the water turbulence.

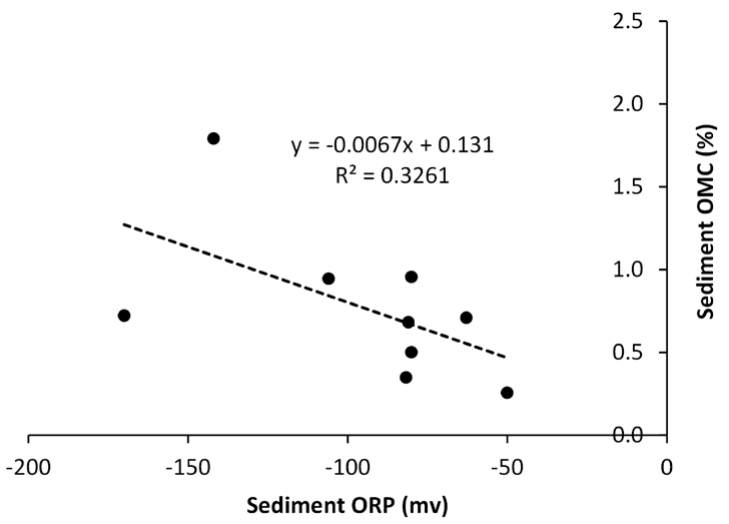

Fig. 4. Relationship between sediment organic matter content (OMC) and the oxygen redox potential (ORP).
$E_{h}$ values were not significantly different (Table 1) among those locations. However, the OMC was significantly correlated to the sediment oxygen redox potential (Fig. 4 and Table 2).

Turbulence induces mixing sediments with overlying water and consequently oxygenates the anoxic sediments. The observed positive correlation between turbulence and sediment redox potential (Table 2) explained the former observation. However, the former trend was not significant $(p>0.05)$.

Although fine sediments accumulated inside reed communities, water turbulence reduces this accumulation (Fig. 5). Coarse particle $(>1000 \mu)$ content was positively correlated to turbulence whereas the same relationships for the fine particles was opposite (Fig. 5). However, none of those relationships were significant (Table 2). The mean flow velocity is efficiently reduced by submersed macro- 
phytes when growing in the entire water column leading to an accumulation of sediments (Fonseca, Fisher, 1986). The sediment accumulation highly depends upon the process of erosion and transportation while both of these processes are functions of current velocity. Fine particles are most easily eroded while the larger particles require faster current to initiate movement (Madsen et al., 2001). The observed positive correlation for coarse particles content and turbulence suggests that the magnitude of turbulence in these areas were strong enough for washing fine sediments. We observed a very low level of mean flow velocities along the transect, i.e. mean flow velocity of outside, water edge, middle and the land ward side of the reed community were $1.02,1.15,0.83$ and $0.98 \mathrm{~cm} \mathrm{~S}^{-1}$ respectively. Therefore the accumulation of fine sediments with the distance interior to the community is probably explained by the observed turbulence reduction. Decreasing flow velocity and turbulent energy content significantly reduce the potential of sediment re-suspension within the aquatic plant communities (Melinda, János, 2104).

Above-ground biomass (AGB) and below-ground biomass (BGB) were not significantly different among three locations (Table 1) while the latter one was always less than the above one. The biomass ratio (AGB: $\mathrm{BGB}$ ) was negatively correlated to water turbulence (Table 2). Mechanical stress induced by water movements allocate comparatively large biomass in below-ground tissues compared to aboveground parts as an adaptive mechanism to withstand against the mechanical stress exerted on reeds by turbulence. That could be a possible explanation for the observed negative correlation for biomass ratio and turbulence. A similar trend was previously observed for Valisnaria spiralis after exposure to turbulence under laboratory conditions (Ellawala et al., 2013), whereas a similar field observation was also reported for some other aquatic plant species (Asaeda et al., 2010b; Bornette, Puijalon, 2011).

Morphological parameters; stem height and diameter of rhizomes of $P$. australis were not significantly different among the three locations (Table 1). The observed stem densities were in the same range as reported in the literature (Coops, Van der Velde, 1996). Although the present study did not observe a significant correlation between plant density and turbulence, Horppila et al. (2013) observed that the maximum turbulence and the duration of strong turbulence as a functions of stem density under laboratory conditions.

Despite observing a positive correlation for rhizome

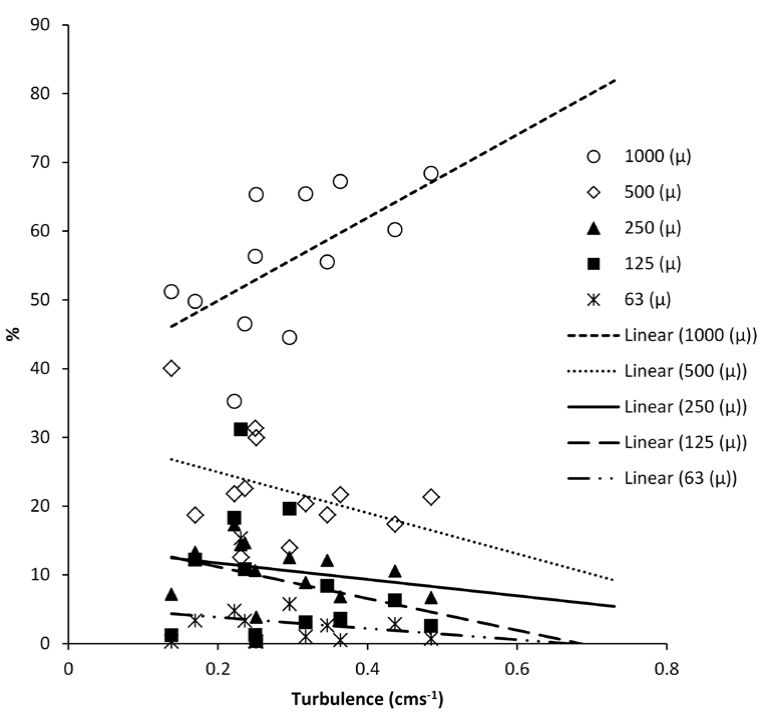

Fig. 5. Relationships between turbulence and sediment composition. 
size and the fine particles content of the bottom sediments, the same relationship for coarse sediments was negative, i.e correlation coefficients for sediment particle sizes of 1000,500 , 250,125 and $62.5 \mu \mathrm{m}$ were $-0.193,-0.092,0.119,0.394$ and 0.355 , respectively. Fine particles would provide better growth and ease of penetration for rhizomes compared to coarse sandy sediments because of mechanical obstruction of sandy beds (Asaeda et al., 2009).

Turbulence has a directly influence on architecture, organic matter accumulation and redox condition of sediments and dissolved oxygen content in surface water in reed communities. However, plant density was less affected. As water movements are considered to be the prime abiotic factor of aquatic macrophytes, our findings can offer insight to clarify the mechanism behind the interactions between plant community, sediment and water movements, and such information would be particularly important in aquatic ecosystem management.

\section{Acknowledgements}

This research was financially supported by Grant-in-Aid for Scientific Research (B) (15H04045) for Japan Society for the Promotion of Science, Research Group of River Ecology, Japanese Ministry of Land, Infrastructure, Transport and Tourism, and the River Fund from the River Foundation". We acknowledge Mr. Miyazawa and Mr. Mochizuki for their assistance during the fieldwork.

\section{References}

Asaeda, T., Siong, K., Kawashima, T. \& Sakamoto K. (2009). Growth of Phragmites japonica on a sandbar of regulated river: morphological adaptation of the plant to low water and nutrient availability in the substrate. River Res. Appl., 25, 874-891. DOI: 10.1002/rra.1191.

Asaeda, T., Gomes, P.I.A. \& Takeda E. (2010a). Spatial and temporal tree colonization in a midstream sediment bar and the mechanisms governing tree mortality during a flood event. River Res. Appl., 26, 960-976. DOI: 10.1002/ rra.1313.

Asaeda, T., Rajapakse, L. \& Kanoh M. (2010b). Fine sediment retention as affected by annual shoot collapse: Sparganium erectum as an ecosystem engineer in a lowland stream. River Res. Appl., 26, 1153-1169. DOI: 10.1002/ rra.1322.

Asaeda, T. \& Shinohara R. (2012). Japanese lakes. In L. Bengtsson, R. Herschy \& R. Fairbridge (Eds.), Encyclopedia of lakes and reservoirs (pp. 415-419). Netherlands: Springer.

Atapaththu, K.S.S. \& Asaeda T. (2015). Growth and stress responses of Nuttall's waterweed Elodea nuttallii (Planch) St. John to water movements. Hydrobiologia, 747, 217-233. DOI: 10.1007/s10750-014-2141-9.

Bal, K.D., Bouma, T.J., Buis, K., Struyf, E., Jonas, S., Backx, H. \& Meire P. (2011). Trade-off between drag reduction and light interception of macrophytes: comparing five aquatic plants with contrasting morphology. Funct. Ecol., 25, 1197-1205. DOI: 10.1111/j.1365-2435.2011.01909.x.

Bernhardt-Römermann, M., Gray, A., Vanbergen, A.J., Bergès, L., Bohner, A., Brooker, R.W., De Bruyn, L., De Cinti, B., Dirnböck, T., Grandin, U., Hester, A.J., Kanka, R., Klotz, S., Loucougaray, G., Lundin, L., Matteucci, G., Mészáros, I., Oláh, V., Preda, E., Prévosto, B., Pykälä, J., Schmidt, W., Taylor, M.E., Vadineanu, A., Waldmann, T. \& Stadler J. (2011). Functional traits and local environment predict vegetation responses to disturbance: a panEuropean multi-site experiment. J. Ecol., 99, 777-787. DOI: 10.1111/j.1365-2745.2011.01794.x.

Bornette, G. \& Puijalon S. (2011). Response of aquatic plants to abiotic factors: a review. Aquatic Sciences, 73, 1-14. DOI: $10.1007 / \mathrm{s} 00027-010-0162-7$.

Chambers, P.A., Prepas, E.E., Hamilton, H.R. \& Bothwell M.L. (1991). Current velocity and its effect on aquatic macrophytes in flowing waters. Ecol. Appl., 1, 249-257. DOI: 10.2307/1941754.

Coops, H. \& Van der Velde G. (1996). Effects of waves on helophyte stands: mechanical characteristics of stems of Phragmites australis and Scirpus lacustris. Aquat. Bot., 53, 175-185. DOI: 10.1016/0304-3770(96)01026-1.

Ellawala, C., Asaeda, T. \& Kawamura K. (2012). The effect of flow turbulence on growth, nutrient uptake and stable carbon and nitrogen isotope signatures in Chara fibrosa. Ann. Limnol., 48, 349-354. DOI: 10.1051/limn/2012024. 
Ellawala, C., Asaeda, T. \& Kawamura K. (2013). Water movement induced variations in growth regulation and metabolism of freshwater macrophyte Vallisneria spiralis L. in early growth stages. Hydrobiologia, 709, 173-182. DOI: $10.1007 / \mathrm{s} 10750-013-1447-3$.

Engloner, A.I. (2009). Structure, growth dynamics and biomass of reed (Phragmites australis) - A review. Flora Morphology, Distribution, Functional Ecology of Plants, 204, 331-346. DOI: 10.1016/j.flora.2008.05.001.

Fonseca, M.S. \& Fisher J.S. (1986). Comparison of canopy friction and sediment movement between four species of seagrass with reference to their ecology and restoration. Mar. Ecol.- Progress Series, 29, 15-22.

Green, J.C. (2005). Velocity and turbulence distribution around lotic macrophytes. Aquat. Ecol., 39, 1-10. DOI: 10.1007/s10452-004-1913-0.

Hans, B. (1994). Functions of macrophytes in constructed wetlands. Water Sci. Technol., 29, 71-78.

Horinouchi, M., Kume, G., Yamaguchi, A., Toda, K. \& Kurata K. (2008). Food habits of small fishes in a common reed Phragmites australis belt in Lake Shinji, Shimane, Japan. Ichthyol. Res., 55, 207-217. DOI: 10.1007/s10228007-0021-2.

Horne, A.J. \& Goldman C.R. (1994). Limnology. New York: McGraw-Hill.

Horppila, J., Kaitaranta, J., Joensuu, L. \& Nurminen L. (2013). Influence of emergent macrophyte (Phragmites australis) density on water turbulence and erosion of organic-rich sediment. Journal of Hydrodynamics, Ser. B, 25, 288-293. DOI: 10.1016/S1001-6058(13)60365-0.

Komuro, T., Sakayamai, H., Kamiya, H. \&Yamamuro M. (2016). Reconstruction of the charophyte community of Lake Shinji by oospore collection. Knowledge and Management of Aquatic Ecosystems, 417, 12. DOI: 10.1051/ $\mathrm{kmae} / 2015045$.

Krolová, M., Čížková, H., Hejzlar, J. \& Poláková S. (2013). Response of littoral macrophytes to water level fluctuations in a storage reservoir. Knowledge and Management of Aquatic Ecosystem, 408, 07. DOI: 10.1051/kmae/2013042.

Leonard, L.A. \& Reed D.J. (2002). Hydrodynamics and sediment transport through tidal marsh canopies. J. Coast. Res. SI, 36, 459-469.

Leonard, L.A. \& Croft A.L. (2006). The effect of standing biomass on flow velocity and turbulence in Spartina alterniflora canopies. Estuar. Coast. Shelf Sci., 69, 325-336. DOI: 10.1016/j.ecss.2006.05.004.

Madsen, J.D., Chambers, P.A., James, W.F., Koch, E.W. \& Westlake D.F. (2001). The interaction between water movement, sediment dynamics and submersed macrophytes. Hydrobiologia, 444, 71-84. DOI: 10.1023/A:1017520800568.

Melinda, K. \& János J. (2014). Measurements-based hydrodynamic characterisation of reed-open water interface zone in shallow lake environment. Periodica Polytechnica Civil Engineering, 58, 229-241. DOI: 10.3311/ PPci.7569.

Olson, E.R., Ventura, S.J. \& Zedler J.B. (2012). Merging geospatial and field data to predict the distribution and abundance of an exotic macrophyte in a large Wisconsin reservoir. Aquat. Bot., 96, 31-41. DOI: 10.1016/j. aquabot.2011.09.007.

Sand-Jensen, K. \& Pedersen O. (1999). Velocity gradients and turbulence around macrophyte stands in streams. Freshw. Biol., 42, 315-328. DOI: 10.1046/j.1365-2427.1999.444495.x.

Schutten, J., Dainty, J. \& Davy A.J. (2004). Wave-induced hydraulic forces on submerged aquatic plants in Shallow Lakes. Ann. Bot., 93, 333-341. DOI: 10.1093/aob/mch043.

Silinski, A., Heuner, M., Schoelynck, J., Puijalon, S., Schröder, U., Fuchs, E., Troch, P., Bouma, T.J., Meire, P. \& Temmerman S. (2015). Effects of wind waves versus ship waves on tidal marsh plants: A flume study on different life stages of Scirpus maritimus. PLoS ONE, 10, e0118687. DOI: 10.1371/journal.pone.0118687.

Struyf, E., Van Damme, S., Gribsholt, B., Bal, K., Beauchard, O., Middelburg, J.J. \& Meire P. (2007). Phragmites australis and silica cycling in tidal wetlands. Aquat. Bot., 87, 134-140. DOI: 10.1016/j.aquabot.2007.05.002.

Thomaz, S., Bini, L. \& Bozelli R. (2007). Floods increase similarity among aquatic habitats in river-floodplain systems. Hydrobiologia, 579, 1-13. DOI: 10.1007/s10750-006-0285-y. 